\title{
Monitoring of biochemical effects of organochlorine pesticides on human health
}

\author{
Sobia Khwaja ${ }^{1^{*}}$, Rubina Mushtaq ${ }^{1}$, Rehana Mushtaq ${ }^{1}$, Masarrat Yousuf $^{2}$, \\ Muhammad Attaullah ${ }^{2}$, Fozia Tabbassum ${ }^{2}$, Rabiya Faiz ${ }^{2}$ \\ ${ }^{1}$ Department of Zoology, Federal Urdu University of Arts, Science and Technology, Karachi, Pakistan; \\ *Corresponding Author: gr8 dezirez@hotmail.com \\ ${ }^{2}$ Department of Zoology, University of Karachi, Karachi, Pakistan
}

Received 2 May 2013; revised 3 June 2013; accepted 15 July 2013

Copyright (C) 2013 Sobia Khwaja et al. This is an open access article distributed under the Creative Commons Attribution License, which permits unrestricted use, distribution, and reproduction in any medium, provided the original work is properly cited.

\section{ABSTRACT}

The present study was designed to analyze organochlorine pesticide residues in the blood samples of the residents of Karachi. Biochemical and hematological parameters were tested thoroughly for changes as a result of organochlorine residues. In the blood samples which were drawn from both genders, organochlorine compounds like $\alpha$-endosulfan $(1.565 \mathrm{mg} / \mathrm{kg})$ and $\beta$-endosulfan (1.233 $\mathrm{mg} / \mathrm{kg})$ were found in higher quantities and were the most frequently detected compounds. Average concentrations of the detected compounds $(\mathrm{mg} / \mathrm{kg})$ were: $\mathrm{HCH}$ (0.819); Cyclodienes (2.839); Diphenylaliphatics (0.240). An evident finding was the alteration in enzyme activity in higher residue samples. Levels of GPT, GOT, ALP, Choline-esterase and $y$-GT were tested in all samples and observed major shifts in the upper and lower limits in high residue samples as compared with the normal values. Analysis of the blood parameters were carried out thoroughly and checked the levels of TLC, RBC, Hb, Hct, MCV, MCH, MCHC, Platelets and differential leucocytes (Neutrophils, Lymphocytes, Eosinophils and Monocytes) but found no distinct changes and hence no convincing relation was observed. Results of the present investigation of OCs in different blood sera indicated that bioconcentration and biomagnification of these chemicals were common phenomena in the population of Karachi city and this may be accountable for a variety of diseases and health hazards.

Keywords: Organochlorine; Enzymes; Blood Parameters

\section{INTRODUCTION}

The economy of Pakistan largely depends on agriculture. It plays a vital role in the income of rural areas which consists of $70 \%$ of the total population. Its contribution is around $25 \%$ to the national economy which is also a source of employment for over $44 \%$ of the labour force. The economy depends upon production, processing and major products distribution like cotton, wheat, edible oil, sugar, meat and milk. During the recent past, this sector grows at an average rate of $4.5 \%$ and has shown changes due to climatic conditions.

According to the Technical Bulletin [1], the use of pesticides in Pakistan has increased by $11.69 \%$ in last 20 years and the number of sprays per crop has reached more than $10 \%$, which is an alarming situation as far as human health is concerned.

The usage of pesticides in Pakistan has raised from 665 tons in the year 1980 to 45,680 tons in 1999. According to Poswal and Williamson [2], the excessive use of pesticides does not surely play a vital role in growth of crops. The dilemma is that pesticides, which developed countries have banned due to their toxic effects, are presently still in practice in the third world countries $[3,4]$. At present, more than 108 types of insecticides, 30 types of fungicides, 39 types of weedicides, 5 types of acaricides, and 6 different types of rodenticides are being used in Pakistan [5]. According to an Economic survey, [6] the import of pesticides is increasing gradually every year.

After its introduction in1940s, the use of organochlorine pesticides was common in agricultural sector for pest control. However, the disadvantages of their use led to the ban and restriction by the government. Even after implementing restrictions and bans on many organochlorine pesticides during 1970s and 1980s, it is observed that they still persist in our environment. 
The organochlorine compounds are hydrophobic, lipophilic and highly stable chemicals. Food is the basic requirement of man, mainly by using animal products where organochlorine compounds may be bioaccumulated and transferred to humans through food chain. Investigations have shown acute and chronic effects of these chemicals which result in neurological and reproductive disorders.

These synthetic pesticides are causing various problems, e.g. pesticidal pollution, resistance in pest and deposition of residues of these pesticides in body of the animals and human beings. This is responsible for great risk to the human health, especially when these pesticides are being sprayed indiscriminately without any proper care and without thinking about the risk to the cattle, poultry, fish farming and the human beings. Ultimately these pesticides reach the human body directly or indirectly.

There are different means which aid in non-occupational pesticide exposure like contact with polluted water, food, soil, clothes or mother's milk or aerial drifting during spraying.

It has been reported that the developing countries use $20 \%$ of the total pesticides while the developed countries use $80 \%$ but the death rate is thirteen times more in developing countries, due to the indiscriminate use or improper pesticides [7]. In the developed countries, many researches are being done on pesticides' resistance, pollution and cumulative effect of pesticides on human beings and pet animals.

For this reason, the developed countries have diverted their attention towards IPM (Integrated Pest Management) program. They are also using phytopesticides, hormonal pesticides etc. to avoid the hazardous effects of synthetic pesticides on human health. Regular check of pesticide residues in food and cereal products is being done and whenever in any commodity pesticide residues is beyond MRL then the whole lot is discarded and destroyed.

Pesticides residue analysis, resistance, pollution and health hazards have been investigated by many researchers worldwide. Naqvi and Jahan reported the presence of pesticide residues in the blood sera and adipose tissues of Karachi citizens [8]. Parveen and Masud found different classes of pesticides in human blood samples in the cotton growing areas [9]. The presence of pesticide residues in blood samples of rural population from Gadap, Karachi [10].

Many researchers have reported the effects of pesticides on various enzymes, especially in case of cholinesterase. Researchers found correlation between RBC cholinesterase and methyl parathion, indicating that pesticides inhibited the AChE [11].

In Pakistan last decade reported [12-14] the effects of pesticides on esterase (cholinesterase and phosphomonoesterase). The effect of residues on enzyme secretion, i.e., GOT, GPT, ALP in the blood of exposed persons [15].

Pesticides may affect the blood parameters. In previous study platelet counts decreases by the effect of pesticides [16]. Another study shows potential relationship between chlorinated hydrocarbons and various blood parameters [17]. Early study shows decrease in RBC count, $\mathrm{Hb}$ concentration, Hct, $\mathrm{MCHC}$ and platelets count due to this pesticide [18].

In the industrialized countries farmers showed melanoma, leukemia, soft tissue sarcoma, brain, breast cancer, non-Hodgkin's lymphoma, kidney, lip, prostate, lung stomach, multiple myeloma and sinonasal cavities very significantly [19,20].

Pesticide exposure has been associated with abnormality in reproduction of male offspring's including hypospadias and cyrptorchidism [21,22]

In current study, chemicals like OCs were quantified in randomly collected blood samples from Karachi population. The studied population age ranged between 25 - 43 years, in which smokers were $73 \%$, tobacco users $39 \%$, and others were $8 \%$. The aim was to examine the OC residues in body of individuals who were indirectly or directly exposed to these organic pesticides.

\section{MATERIALS AND METHODS}

The study was undertaken after endorsement from participants institutional review boards and in agreement with an assurance filed.

\section{a) Collection of blood samples}

Blood samples were collected randomly from persons living in different areas of Karachi into vacuity blood collection polypropylene tubes $(5 \mathrm{ml})$. The sera from the blood were then separated by centrifugation and were transferred to new blood tubes. These samples were kept into iced flask and stored at $-20^{\circ} \mathrm{C}$ until further analysis.

\section{b) Extraction of serum}

Aliquot of $5 \mathrm{ml}$ of serum was equilibrated to room temperature and $2 \mathrm{ml}$ of methanol was added then the sample was agitated for $1 \mathrm{~min}$. and $5 \mathrm{ml} \mathrm{n}$-hexane, diethyl ether $(1: 1 \mathrm{v} / \mathrm{v})$ was added and again agitated for $2 \mathrm{~min}$. The sample was then centrifuged for $5 \mathrm{~min}$. at 3000 round per minute. After centrifugation the organic phase was separated and the aqueous phase was extracted twice with diethyl ether, $\mathrm{n}$-hexane $(1: 1 \mathrm{v} / \mathrm{v})$. The organic phase was reduced and concentrated to $1 \mathrm{ml}$ by evaporation in a vaccum concentrator. Then $\mathrm{H}_{2} \mathrm{SO}_{4}$ was added into the concentrated $1 \mathrm{ml}$ sample of organic phase, shaked for 1 min. and centrifuge for $5 \mathrm{~min}$. at $3000 \mathrm{rpm}$. The organic mixture was collected and the aqueous phase was removed twice with $\mathrm{n}$-hexane $(1 \mathrm{ml})$. The organic phases 
were concentrated and dried completely in a vaccum concentrator. The dry residues were mixed in n-hexane (1 ml) for clean-up procedure [23].

\section{c) Florosil Column for Extracted Serum}

The organic extract was passed into a glass column, containing $1 \mathrm{~g}$ florisil topped with $1.0 \mathrm{~g}$ anhydrous $\mathrm{Na}_{2} \mathrm{So}_{4}$. The column was prewashed with $20 \mathrm{ml}$ hexane. The compounds retained on the column were then eluated with hexane until the collected eluates had a total volume of $25 \mathrm{ml}$. The eluate was evaporated to dryness and analyzed by GC-ECD after proper dilution.

\section{d) Hematological Investigation}

Whole blood samples were selected to confirm any possible effect of pesticides on: WBC, RBC, Hb, Hct, red cell indices (MCV, MCH, MCHC) and Platelets. In addition, differential blood count was also examined. A complete blood count (CBC) was also undertaken.

e) Determination of Differential Leucocytes (DLC)

The purpose of the differential WBC Count is to examine a sample of blood and found the relevant percentages of WBC in each samples.

\section{f) Enzymatic Determination}

For enzymatic determination, the collected serum samples were kept in clean and labeled plastic vials. The different enzymes were determined by using automated Merk Vitalab Micro-200 biochemical analyzer that have well controlled programming system to confirm any toxic inhibitory effects produced in the body of the persons due to prolonged pesticides exposure.

\section{RESULTS}

\subsection{Residues of Pesticides}

The sum of mean of organochlorine pesticides in serum was $3.898 \mathrm{mg} / \mathrm{kg}$. In serum samples $\mathrm{HCH}$ isomers were found in the following order like $\beta$ - $\mathrm{HCH}(8 \%)<$ $\alpha$-HCH $(12 \%)<\gamma$ and $\alpha \mathrm{HCH}(16 \%) . \beta-\mathrm{HCH}$ showed highest mean value as $0.650 \mathrm{mg} / \mathrm{kg}$.

The derivatives of heptachlor found in $14 \%$ of the collected samples with the sum of mean level as 0.031 $\mathrm{mg} / \mathrm{kg}$. Somewhat similar values for Aldrin and Endrin concentration were found in tested serum samples (Table 1). The mean concentration of Endrin was obtained as $0.002 \mathrm{mg} / \mathrm{kg}$ with values ranging between 0.0001 and $0.024 \mathrm{mg} / \mathrm{kg}$. Aldrin did not exceed from $0.022 \mathrm{mg} / \mathrm{kg}$. The samples which were positive for Aldrin concentrations range from 0.0001 to $0.017 \mathrm{mg} / \mathrm{kg}$. The mean values $0.003 \mathrm{mg} / \mathrm{kg}$ and $0.005 \mathrm{mg} / \mathrm{kg}$ were calculated for Endosulfan sulfate and Dieldrin. Beside Cyclodienes various DDT derivatives were found in the following manners as 4,4 DDE > 4,4 DDT > 4,4 DDD. The sum of mean levels of these derivatives was $0.009 \mathrm{mg} / \mathrm{kg}$. The most frequently detected organochlorine compounds were $\alpha$-Endosulfan, $\beta$-Endosulfan, 4,4DDE and Methoxychlor.

Table 1. Descriptive statistical data of pesticide residues in serum samples.

\begin{tabular}{|c|c|c|c|c|c|}
\hline Name of Pesticides & Positive test (\%) & Mean & SD & SE & Range min-mix \\
\hline$\alpha-\mathrm{HCH}$ & 12.5 & 0.0006 & 0.002 & 0.0005 & $0.000-0.002$ \\
\hline$\beta-\mathrm{HCH}$ & 8.3 & 0.650 & 3.120 & 0.636 & $0.026-2.523$ \\
\hline$\gamma-\mathrm{HCH}$ & 16.6 & 0.112 & 0.368 & 0.075 & $0.071-0.367$ \\
\hline$\delta$-HCH & 16.6 & 0.056 & 0.246 & 0.050 & $0.011-0.208$ \\
\hline$\Sigma \mathbf{H C H}$ & & 0.819 & & & \\
\hline Heptachlor & 12.5 & 0.0007 & 0.003 & 0.0006 & $0.000-0.002$ \\
\hline Hepta-end-epoxide & 16.6 & 0.029 & 0.082 & 0.016 & $0.024-0.090$ \\
\hline Hepta-exo-epoxide & 12.5 & 0.001 & 0.004 & 0.0008 & $0.000-0.004$ \\
\hline Aldrin & 16.6 & 0.001 & 0.005 & 0.001 & $0.001-0.005$ \\
\hline Endrin & 16.6 & 0.002 & 0.007 & 0.001 & $0.002-0.007$ \\
\hline$\alpha$-Endosulfan & 75 & 1.565 & 3.113 & 0.635 & $1.821-4.313$ \\
\hline$\beta$-Endosulfan & 41.6 & 1.233 & 2.648 & 0.540 & $1.357-3.476$ \\
\hline Endosulfan Sulfate & 16.6 & 0.003 & 0.009 & 0.001 & $0.002-0.010$ \\
\hline Dieldrin & 29.1 & 0.005 & 0.019 & 0.003 & $0.003-0.019$ \\
\hline 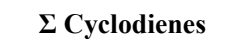 & & 2.839 & & & \\
\hline 4,4-DDT & 25 & 0.003 & 0.011 & 0.002 & $0.003-0.012$ \\
\hline 4,4 DDE & 41.6 & 0.005 & 0.009 & 0.001 & $0.007-0.015$ \\
\hline 4-4,DDD & 20.8 & 0.001 & 0.006 & 0.001 & $0.001-0.006$ \\
\hline Methoxychlor & 58.3 & 0.231 & 0.383 & 0.078 & $0.300-0.607$ \\
\hline ¿Diphenylaliphatic & & 0.240 & & & \\
\hline
\end{tabular}




\subsection{Enzyme Levels in Serum}

The blood samples were also examined for enzyme levels, i.e. GPT, GOT, ALP, Cholinesterase, $\gamma$-GT and Total protein. The different patterns of enzyme levels in persons from different areas of Karachi are shown in Table 2.

Among twenty four collected blood samples, only four were from female donors.

GPT was found to be in high levels as $57 \mu / 1$ (sample 9), $74 \mu / 1$ (sample19) and $89 \mu / 1$ in sample 22 . GPT was also slightly high as $42 \mu / 1$ in sample 10 . Rest of the samples showed normal levels. These values are noted after comparing with their normal values.

GOT was highest in a male donor aged 31 years, i.e. $264 \mu / 1$ (sample 11). A 10 years old child showed the highest level of GOT as $198 \mu / 1$ (sample 1). The other samples [2,7-9,11,14,16.18,20,21] also showed high levels of GOT. Normal limit of GOT was found in remaining samples as shown in Table 2.

Table 2. Level of different enzymes in blood donors.

\begin{tabular}{|c|c|c|c|c|c|}
\hline \multicolumn{6}{|c|}{ Enzymes Activity } \\
\hline Serial \# & GPT & GOT & ALP & Cholin. & $\gamma \mathrm{GT}$ \\
\hline 1 & 10 & 198 & 30 & 4,917 & 8 \\
\hline 2 & 30 & 165 & 41 & 21,175 & 45 \\
\hline 3 & 15 & 20 & 145 & 15,811 & 17 \\
\hline 4 & 24 & 30 & 990 & 4,565 & 36 \\
\hline 5 & 16 & 19 & 203 & 15,356 & $\underline{10}$ \\
\hline 6 & 17 & 37 & 192 & 14,057 & 21 \\
\hline 7 & 26 & 218 & 172 & 20,054 & 21 \\
\hline 8 & 19 & 199 & 206 & 24,214 & 16 \\
\hline 9 & 57 & 130 & 172 & 21,327 & $\underline{11}$ \\
\hline 10 & 42 & 196 & 170 & 27,886 & $\underline{5}$ \\
\hline 11 & 35 & 264 & 246 & 09,100 & 30 \\
\hline 12 & 24 & 16 & 132 & 12,110 & 20 \\
\hline 13 & 11 & 21 & 166 & 23,547 & 19 \\
\hline 14 & 13 & 249 & 217 & 14,240 & 18 \\
\hline 15 & 18 & 14 & 35 & 20,368 & 15 \\
\hline 16 & 22 & 98 & 115 & $\underline{1,861}$ & $\underline{10}$ \\
\hline 17 & 35 & 23 & 98 & 10,074 & 30 \\
\hline 18 & 34 & 76 & 196 & 20,152 & $\underline{8}$ \\
\hline 19 & 74 & 47 & 196 & 7,282 & 19 \\
\hline 20 & 32 & 77 & 166 & $\underline{1,815}$ & 12 \\
\hline 21 & 20 & 17 & 274 & 4,786 & 14 \\
\hline 22 & 29 & 97 & 157 & 25,510 & 55 \\
\hline 23 & 10 & 13 & 97 & 21,989 & 16 \\
\hline 24 & 89 & 31 & 96 & 17,034 & 38 \\
\hline
\end{tabular}

Bold $=$ High values, underline $=$ Low values.
ALP was detected in normal values in three samples out of twenty four samples. A female donor aged 55 showed the highest level of ALP, i.e. $990 \mu / 1$ (sample 4). In males, highest ALP level was found as $27 \mu / 1$ in (sample 21) (Table 2).

Cholinesterase level exceeded from its normal limits in seventeen samples. In sample 10 the cholinesterase level was highest i.e. $27,886 \mu / 1$ as compared to other high values. In samples 16 and 20, inhibition of the enzyme cholinesterase was noted i.e. $1861 \mu / 1$ and $1815 \mu / 1$ respectively. Only five samples showed normal values of cholinesterase.

High level of $\gamma$-GT was found in three samples i.e. 45 $\mu / 1$ (sample 2), $336 \mu / 1$ (sample 4) and $55 \mu / 1$ (sample 22) while lower values of $\gamma$-GT was found in five samples i.e. $10 \mu / 1$ (sample 5), $11 \mu / 1$ (sample 9), $5 \mu / 1$ (sample10), 10 $\mu / 1$ (sample 16) and $8 \mu / 1$ in sample 18 . Rest of the samples showed normal values of $\gamma$-GT (Table 2).

\subsection{Blood Parameters}

Complete blood count was also checked beside enzyme levels in each donor to observe the effect of pesticides on different blood parameters. These parameters were TLC, RBC count, Hb, Hct, MCV, MCH, MCHC, Platelets count and DLC in each donor as given in Table 3.

TLC showed highest value only in one person (sample 4) aged 55 years, i.e., 22.6 (Thsd/ul) while two persons showed lower limits of leucocytes i.e., 3.4Thsd/ul (sample 6) and 3.8Thsd/ul (sample 14). Rest of the samples showed normal total leucocytes count.

Red Cell count was found at lower limits in nine samples. The lowest value of RBC in female donor was as observed 3.4 Mill/ul (sample 2) whereas in male showed 3.9 Mill/ul (sample 9). RBC count was observed in two samples (12 \& 17). Rest of the samples had normal limits of red cells (Table 3 ).

$\mathrm{Hb}$ was found higher in two donors but lower limits were found in 7 samples out of twenty five. In a female donor (10 years old), the lowest limit of $\mathrm{Hb}$, i.e., 8.9 $\mathrm{gm} / \mathrm{dl}$ was noted while in an adult of 5 years old 8.9 $\mathrm{gm} / \mathrm{dl}$ was observed (sample 4). In a male donor (sample 5) the lowest value of $\mathrm{Hb}$, i.e., $11.3 \mathrm{gm} / \mathrm{dl}$ was calculated. Normal values for $\mathrm{Hb}$ were observed in rest of the serum samples (Table 3).

Hct was found in higher limits in 2 person but lower limits were found in six samples. All female donors showed lower limits of Hct, i.e., 27\% (sample 1), 33\% (sample 2), 34.5\% (sample 3) and 145\% (sample 4). Among males two donors showed lower limits.

Highest value of MCV was calculated in a female donor (sample 4), i.e., 97fl. Sample 6 and 7 showed similar high values of $\mathrm{MCV}$, i.e., $98 \mathrm{fl}$ and $99 \mathrm{fl}$. Rest of the 
Table 3. Blood parameters of blood donors.

\begin{tabular}{|c|c|c|c|c|c|c|c|c|}
\hline S.No. & TLC & RBC & $\mathbf{H b}$ & Hc & MCV & МСH & МCHC & PIt \\
\hline 1 & 15.1 & $\underline{3.5}$ & $\underline{8.9}$ & $\underline{27}$ & 80 & 28 & 33 & 159 \\
\hline 2 & 9.3 & $\underline{3.4}$ & 11.0 & $\underline{33}$ & 90 & 30 & 36 & 205 \\
\hline 3 & 6.3 & $\underline{3.9}$ & $\underline{11.5}$ & $\underline{34.5}$ & 86.7 & 28.8 & 33.3 & 289 \\
\hline 4 & 22.6 & $\underline{3.8}$ & $\underline{8.9}$ & $\underline{14}$ & 97 & 32 & 36.5 & 291 \\
\hline 5 & 5.9 & $\underline{3.91}$ & $\underline{11.3}$ & $\underline{35.8}$ & 91.6 & 28.9 & 31.6 & 179 \\
\hline 6 & $\underline{3.4}$ & 5.3 & 16.0 & 48 & 98 & 32 & 36 & 380 \\
\hline 7 & 6.4 & 5.5 & 16.5 & 49 & 98 & 32 & 36 & 290 \\
\hline 8 & 6.9 & 4.7 & 14.2 & 43 & 93 & 31 & 34 & 280 \\
\hline 9 & 6.1 & $\underline{3.9}$ & $\underline{11.8}$ & $\underline{35}$ & 80 & 30 & 32 & 268 \\
\hline 10 & 4.0 & $\underline{4.0}$ & $\underline{11.9}$ & 36 & 82 & 30 & 33 & 255 \\
\hline 11 & 8.8 & 4.5 & 13.6 & 41 & 88 & 31 & 33 & 295 \\
\hline 12 & 4.9 & 5.7 & $\underline{11.5}$ & 43 & 89 & 30 & 34 & 276 \\
\hline 13 & 8.8 & 4.8 & 14.6 & 44 & 88 & 32 & 34 & 344 \\
\hline 14 & $\underline{3.8}$ & 5.0 & 13.6 & 39 & 84 & 32 & 33.2 & 382 \\
\hline 15 & 9.2 & 5.0 & 15.1 & 45 & 96 & 30 & 33 & 190 \\
\hline 16 & 4.2 & 5.3 & 13.5 & 41.8 & 78.6 & $\underline{25.4}$ & 32.3 & $\underline{147}$ \\
\hline 17 & 7.3 & 5.8 & 12.0 & 36 & 82 & 29 & 32 & 290 \\
\hline 18 & 5.8 & $\underline{4.4}$ & 13.2 & 40 & 89 & 31 & 35 & 240 \\
\hline 19 & 9.8 & $\underline{4.3}$ & $\underline{12.8}$ & 38 & 86 & 30 & 33 & 340 \\
\hline 20 & 7.8 & 4.7 & 14.0 & 42 & 93 & 32 & 34 & 190 \\
\hline 19 & 9.4 & 4.6 & 13.8 & 41 & 99 & 31 & 36 & 210 \\
\hline 20 & 4.2 & 4.4 & 13.2 & 40.1 & 90.2 & 29.8 & 33.0 & 222 \\
\hline 21 & 4.9 & 4.7 & 14.3 & 43 & 89 & 30 & 34 & 350 \\
\hline 22 & 5.7 & 4.7 & 14.2 & 43 & 92 & 31 & 34 & 344 \\
\hline 23 & 7.5 & 4.8 & 14.4 & 37 & 92 & 30 & 33 & 350 \\
\hline 24 & 11.5 & $\underline{4.0}$ & 11.9 & 43 & 88.6 & 30 & 33 & 255 \\
\hline
\end{tabular}

Bold $=$ High values, underline $=$ Low values

samples showed normal values without any remarkable change.

MCHC was found in higher level in one donor, i.e., $36.5 \mathrm{THsd} / \mathrm{ul}$. All other samples have normal values.

Platelets were found slightly below the lower limit, i.e., $147 \mathrm{THsd} / \mathrm{ul}$ in sample 16. Higher limit was not crossed in any of the sample.

\section{DISCUSSION}

Organochlorine compounds are very persistent organic pollutants which because of their lipophilic properties are deposited in fat tissues of living organisms and causes serious health hazards with the passage of time.

In the present investigation, chlorinated residues are found in almost every individual, although their use was banned many years ago. The concentration of organochlorine compounds were detected and quantified in samples by GC-ECD technique. The production of most of these organochlorines is banned in most of the countries as a result of their known broad spectrum effects on animals and humans. The results of present study indicate that organochlorine compounds are still present in samples of human biological materials of Karachi population. 
The level of $\beta$ - HCH was $0.650 \mathrm{mg} / \mathrm{kg}$ in serum samples of subjects which is higher than $(0.507 \mu \mathrm{g} / \mathrm{l})$ reported in the agricultural workers of Brazil (23). The sum of three HCH isomers $(\alpha, \beta, \delta)$ was found in mean level of $7.3 \mathrm{ng} / \mathrm{g}$ in the serum of farmers from Ghana that is comparatively lower than $0.818 \mathrm{mg} / \mathrm{kg}$ of $\mathrm{HCHs}(\alpha, \beta$, $\gamma, \delta)$ in general population of Karachi.

These results indicate that relatively high source of HCHs are still present in the environment of Karachi city and technical HCH may be illegally used for public health purposes and people are being exposed to HCHs. The biological half lives of $\mathrm{HCHs}$ are shorter than the other OCs. It means that these samples were contaminated recently with $\mathrm{HCH}$ isomers. Of all the $\mathrm{HCH}$ isomers, only lindane has insecticidal properties and it is present in 44 phytosanitary products. Lindane is commonly used in agriculture for treating soils and in the cultivation of sugar cane, maize, sorghum, citric fruits tree and wheat. It is also used in certain anti-parasitic preparations for tropical use in humans. Lindane $(\gamma-\mathrm{HCH})$ is banned in Pakistan [24] but the result from the present findings shows persistency of $\mathrm{HCH}$ in human biological materials. The plausible source may be old stock of HCHs probably available in Pakistan stock houses by private entrepreneurs and public for insect control in their premises. Lindane is stored in Punjab province of Pakistan at 42, 655, $94 \mathrm{~kg}$ quantity [24].

The cyclodienes appeared after World War II. Most of them are reported to be persistent insecticides that exist in soil and are very much stable to ultraviolet rays. Hence they were excessively used in higher ratios as soil insecticides (for example dieldrin, heptachlor and aldrin) to control termite colonies and insects which are soil dwellers. The cyclodienes were reported as the most effective and economical termiticides ever introduced. Excessive usage of cyclodienes was banned by the EPA from 1975 to 1980 and their use in the form of termiticides was prohibited during 1984 - 1988. It is well-known that this class affects the inhibitory mechanism of GABA (g-amino butyric acid) receptor. Cyclodienes resist chloride ions from reaching the nerve cells and therefore antagonize the "calming effects of GABA." (http://www.ehow.com).

In the present study $45 \%$ of blood samples were from government employees belonging to different hazardous chemical godowns.

The diphenylaliphatics among the OCs are reported to be the oldest group of OC pesticides. In the $20^{\text {th }}$ century DDT is reported to be the most hazardous chemical. It is also considered as the most active insecticide ever introduced. It is being used for malaria control in many third world countries. Agricultural usage of DDT is still continuing although it is banned in many countries [25].

In Pakistan found OC pesticides in blood monitoring study area of Multan, Pakistan. They reported that the most frequently detected pesticide was DDT and its metabolites i.e. $42.6 \%$ ( 75 samples) which is greater than the present report conducted in Karachi which investigated about $29.2 \%$ (24 samples) of DDT in serum samples (9). The endocrine disruptive pesticides/chemicals including DDT, PCBs, TCDD, BHA, TBT and DEHP still use in Pakistan although these chemical have been banned by the higher authorities [26]. The result of this study revealed that the range of 4,4-DDE concentration in serum among Karachi people is from 0.007 to 0.015 $\mathrm{mg} / \mathrm{kg}$. [27] have reported 0.002 to $0.033 \mathrm{ppm}$ DDE in the blood serum from India, $268 \mathrm{ng} / \mathrm{g}$ of DDT in blood sera from the population of Island of Lapalma [28].

$p, p$-DDT is biochemically dechlorinated in human tissues to $p, p$-DDD. Then it is either metabolized or excreted directly from the body [29]; whereas $p, p$-DDE storage in the tissues occurs by direct ingestion of $p, p$ DDE degraded in the environment rather than from the direct ingestion and degradation of $p, p$-DDT [30]. The biological half lives of $p, p$-DDT and $p, p$-DDE depends on their concentration in the tissues. The half-life of $p, p$-DDT is estimated to be greater than 2 years $[31,32]$. $p, p$-DDE is more persistent than DDT and hence it remains in the body substantially for longer time.

There are several studies in Pakistan regarding DDT residues in soil specimens [33,34] and their findings are similar to the researchers in developed world aforesaid $[35,36]$. The general population could receive about $90 \%$ of its stored DDT from food stuffs [37]. Pesticide residues have been reported in milk, seed, cottonseed, different fruits, vegetables and fish meat in Pakistan [38-42]. The data of these researchers show that the majority of samples are contaminated by chlorinated pesticides.

Traces of pesticides are detected in shallow drinking water wells of Pakistan nearby the areas where pesticides were heavily used [43-45]. The usage of DDT in Pakistan was restricted since the late 1970 's. The toxicological study of the current finding shows that the use of this banned pesticide is still in practice which is certainly illegal.

DDT is widely available in Pakistani marketplaces and people continue buying and spraying it in their homes to get rid of bugs, mosquitoes and many household insect pests. [46].

Correlation between enzymes and pesticide metabolism has been reported by various researchers. The inhibition of AChE and BuChE on the RBC membrane and plasma in blood of human beings by the treatment of methylparathion [11] the inhibition of AChE by using DFP [47] similarly the inhibition of ChE by single injection of chlorpyrifos in the CNS [48].

Previous study shows the impact of pesticides exposure on the performance of serum $\mathrm{ChE}$ among 60 paddy 
farmers. The SChE activity was reduced due to pesticide exposure [49].

The prevalence of symptom of AChE inhibition among Kenya agriculture workers researchers found that prolong exposure and higher concentration of pesticides affects the enzymes more than low dose and short term exposure [50].

Enzyme pesticide correlation is investigated by a few researchers in Pakistan $[8,10,51]$ but the subject did not get comprehensive attention in human.

RBC count got elevated in persons having high DDE concentration in the blood serum [17]. In the present study, high lymphocyte count was found in highly exposed cases to pesticides (Table 3) and sample 13, 15, 18,23 . This may be due to the development of immunity against pesticides in these persons. Moreover, detoxifying enzyme levels were also high in these people e.g., cholinesterase, ALP etc. (Table 2). Mostly decreased $\mathrm{RBC}, \mathrm{Hb}, \mathrm{Hct}, \mathrm{MCV}$ and $\mathrm{MCH}$ monocytes count had been observed in such persons. Similarly, low platelet counts by the exposure of dichloropropanol [16]. The low RBC count in persons exposed to chlorinated hydrocarbons. They also reported low $\mathrm{Hb}$ and eosinophil count [17]. Fujitani et al. also reported low RBC count, low $\mathrm{Hb}$ concentration, $\mathrm{Hct}, \mathrm{MCHC}$ and platelet counts in rats exposed to carbamate pesticides [18]. High RBC counts in rats whereas low $\mathrm{RBC}, \mathrm{Hb}, \mathrm{MCV}, \mathrm{MCH}$ values were observed in the fish Talapia nilotica [52]. In previous study found association among chronic lymphocytic leukemia and pesticide exposure among Egyptian farmers. They reported higher lymphocytes, WBC and platelet counts. In the present case $30 \%$ of the serum donors had high lymphocytes values [53].

\section{CONCLUSION}

In the present investigation, it may be concluded that Karachi people have obvious quantities of OC compounds in their serum. This can be concluded in samples as the local population of Karachi is heavily exposed to cyclodienes, moderately exposed to $\mathrm{HCH}$ and lightly exposed to diphenylaliphatic group. The disturbance in enzyme activity in person indicates us that $\mathrm{OC}$ compound level disturbs the normal biological function of human. So in future, it is necessary to check the enzyme activity in pesticides preparing manufacturing workers regularly in general population early as the population is also accumulating OC compounds because any alteration in majors may produce liver lesions and other disorders.

\section{REFERENCES}

[1] Technical Bulletin (2000) Directorate of pest warning and quality control of pesticides. Punjab.
[2] Poswal, M.A. and Williamson, S. (1998) Stepping off the cotton pesticide treadmill: Preliminary findings from a farmer's participatory in Pakistan. CABI Bioscience centre, Rawalpindi.

[3] Wilson, C. and Tisdell, C. (2001) Why farmers continue to use pesticides despite environmental, health and sustainability costs. Ecological Economics, 39, 449-462. doi:10.1016/S0921-8009(01)00238-5

[4] Sankararamakrishnan, N., Sharma, A.K. and Sanghi, R. (2005) Organochlorine and organophosphorous pesticide residues in groundwater and surface waters of Kanpur, Uttar Pradesh, India. Environment International, 31, 113120. doi:10.1016/j.envint.2004.08.001

[5] PPSGDP (2002) Environmental assessment and water quality monitoring program. Irrigation and Power Development, Government of the Punjab, Pakistan Technical Report 54. Punjab Private Sector Groundwater Development Project, Punjab.

[6] Economic Survey of Pakistan (2006) Finance Division, Government of Pakistan, Islamabad.

[7] WHO/UNCEP (1990) Public health impact of pesticides used in agriculture. Working Group, Geneva.

[8] Naqvi, S.N.H. and Jahan, M. (1999) Pesticide residues in serum and blood samples of the people of Karachi. Journal of Environmental Biology, 20, 241-244.

[9] Parveen, Z. and Masud, S.Z. (2001) Studies of pesticide residues in human blood. Pakistan Journal of Science and Industrial Research, 44, 137-141.

[10] Azmi, M.A., Naqvi, S.N.H. and Azmi, M.A. (2005) Pesticide residues in the blood of rural population from Gadap, Karachi and related health hazards. Journal of Experimental Zoology India, 8, 343-351.

[11] Venkataraman, B.V., Rani, M.A., Andrade, C. and Joseph, T. (1994) Correlation of time course of blood cholinesterase activity and toxic manifestations of acute methyl parathion in antidote treated rats. Indian Journal of Physiology and Pharmacology, 38, 214-216.

[12] Khan, M.F., Khan, M.I., Aslam M. and Naqvi, S.N.H. (2000) Study of cholinesterase level in blood of cotton field workers exposed to pesticides. Journal of Baqai Medical University, 3, 12-16.

[13] Akhtar, K. and Naqvi, S.N.H. (2001) Determination of DDT by GLC in different strains of Musca domestica by using hexane as well as diethyl ether. Turkish Journal of Zoology, 25, 77-81.

[14] Khan, M.Z., Naqvi, S.N.H., Khan, M.F., Rahila, T., Ahmed, I. and Earina, F. (2002) Induced effect of Biosal on GOT and GPT in wildlife species of Agama lizard Calotes versicolor. Pakistan Journal of Biological Sciences, $\mathbf{4}$, 611-612.

[15] Azmi, M.A., Naqvi, S.N.H., Azmi, M.A. and Aslam, M. (2006) Effects of pesticide residues on health and different enzyme kevels in the blood of farm workers from Gadap (rural area) Karachi-Pakistan. Chemosphere, 64, 1739-1744. doi:10.1016/j.chemosphere.2006.01.016

[16] Fujishiro, K., Imazu, K., Makita, Y. and Inoue, N. (1994) Liver injury induced by dichloropropanols changes in the time course on hematological and blood chemical exami- 
nations. Fukuoka. Igaku Zasshi, 85, 247-250.

[17] Dunstan, R.H., Roberts, T.K., Donohoe, M., McGregor, N.R., Hope, D., Taylor, W.G., Watkins, J.A., Murdoch, R.N. and Butt, H.L. (1996) Bioaccumulated chlorinated hydrocarbons and red/white blood cell parameters. Biochemical and Molecular Medicine, 58, 77-84. doi:10.1006/bmme.1996.0035

[18] Fujitani, T., Tada, Y., Noguchi, A.T. and Yoneyama, M. (1997) Hemotoxicity of chloroform (CIPC) in F344 rats. Toxicology, 123, 111-124. doi:10.1016/S0300-483X(97)00113-3

[19] Davis, D.L., Bradlow, H.L., Wolff, M., Woodruff, T., Hoel, D.G. and Anton-Culver, H. (1993) Medical hypothesis: Xenoestrogens as preventable causes of breast cancer. Environmental Health Perspectives, 101, 372-377. doi:10.1289/ehp.93101372

[20] McDuffie, H. (1994) Women at work-agriculture and pesticides. Journal of Occupational and Environmental Medicine, 36, 1240-1246. doi:10.1097/00043764-199411000-00012

[21] Kristensen, P., Irgens, I.M., Andersen, A., Bye, A.S. and Sundheim, L. (1997) Birth defects among offspring of Norwegian farmers, 1967-1991. Epidemiology, 8, 537544. doi:10.1097/00001648-199709000-00011

[22] Gray, L.E., Ostby, J., Furr, J., Wolf, C.J., Lambright, C. and Parks, L. (2001) Effect of environmental antianderogens on reproductive development in experimental animals. Human Reproduction Update, 7, 248-264. doi:10.1093/humupd/7.3.248

[23] Frias, M.M., Frenich, A.G., Martinez Vidal, J.L., Sanchez, M.M., Olea, F. and Olea, N. (2001) Analyses of lindane, vinclozolin, aldrin, $\mathrm{p}, \mathrm{p}^{\prime}$-DDE, o, $\mathrm{p}^{\prime}$-DDT and $\mathrm{p}, \mathrm{p}^{\prime}$-DDT in human serum using gas chromatography with electron capture detection and tandem mass spectrometry. Journal of Chromatography B, 760, 1-15.

[24] Tariq, M., Afzal, S., Hussain, I. and Sultana, N. (2007) Pesticides exposure in Pakistan: A review. Environment International, 33, 1107-112. doi:10.1016/j.envint.2007.07.012

[25] Smith, D. (1998) Worldwide trends in DDT levels in human breast milk. International Journal of Epidemiology, 28, 179-188. doi:10.1093/ije/28.2.179

[26] Ejaz, S., Akram. W., Lim. C.W.J.J. and Hussain, I. (2004) Endocrine disrupting pesticides: A leading cause of cancer among rural people in Pakistan. Experimental Oncology, 26, 98-105.

[27] Subramaniam, K. and Solomon, RD.J. (2006) Organochlorine pesticides BHC and DDE in human blood in and around Madurai, India. Indian Journal of Clinical Biochemistry, 21, 169-172.

[28] Zumbado, M., Goethals, M., Alvarez-leon, E.E., Luzardo, O.P., Cabrera, F., Serra-Majem, L. and Dominguez-Boada, L. (2005) Inadvertent exposure to organochlorine pesticides DDT and derivatives in people from the Canary Islands (Spain). Science of the Total Environment, 339, 4962. doi:10.1016/j.scitotenv.2004.07.022

[29] Kutz, F.W., Yobs, A.R. and Strassman, S.C. (1976) Organochlorine pesticide residues in human adipose tissues.
Bull Soc. Pharmacol. Environ. Pathol., 4, 17-19.

[30] Duarte-Davidson, R., Wilson, S.C. and Jones, K.C. (1994) PCBs and other organochlorines in human tissue samples from the Welsh population: II-milk. Environmental Pollution, 84, 79-87. doi:10.1016/0269-7491(94)90073-6

[31] Hayes, W.J., Dale, W.E. and Pirkle, C.I. (1971) Evidence of safety of long-term, high, oral doses of DDT for man. Archives of Environmental Health, 22, 119-135. doi:10.1080/00039896.1971.10665822

[32] Morgan, D.P. and Roan, C.C. (1974) The metabolism of DDT in man. Essays in Toxicology, 5, pp. 39-97.

[33] Sanpera, C., Ruiz, X., Llorente, G.A., Jover, L. and Jabeen, R. (2002) Persistent organochlorine compounds in sediment and biota from the Haleji Lake: A wild life sanctuary in south Pakistan. Bulletin of Environmental Contamination and Toxicology, 68, 237-244. doi:10.1007/s001280244

[34] Tariq, M.I., Afzal, S. and Hussain, I. (2006) Degradation and persistence of cotton pesticides in sandy loam soils from Punjab, Pakistan. Environmental Research, 100, 184196. doi:10.1016/j.envres.2005.05.002

[35] Abrahams, P.W. (2002) Soils: Their implications to human health. Science of the Total Environment, 291, 1-32. doi:10.1016/S0048-9697(01)01102-0

[36] Burauel, P. and Bassmann, F. (2005) Soil as filter and buffer for pesticides-Experimental concept to understand soil functions. Environmental Pollution, 133, 11-16. doi:10.1016/j.envpol.2004.04.011

[37] WHO (1979). DDT and its derivatives. Environment Health Criteria, 9, WHO, Geneva.

[38] Parveen, Z., Afridi, I.A.K., Masud, S.Z. and Baig, M.M.H. (1996) Monitoring of multiple pesticides in cotton seeds during three crop seasons. Pakistan Journal of Science and Industrial Research, 39, 146-149.

[39] Parveen, Z., Khuhro, M.I., Rafiq, N. and Kasuar, N. (2004) Evaluation of multiple pesticide residues in apple and citrus fruits, 1999-2000. Bulletin of Environmental Contamination and Toxicology, 73, 312-318. doi:10.1007/s00128-004-0429-6

[40] Hussain, S., Masud, T. and Ahad, K. (2002) Determination of pesticides in selected varieties of mango. Pakistan Journal of Nutrition, 1, 41-42. doi:10.3923/pjn.2002.41.42

[41] Munshi, A.B., Detlef, S.-B., Schneider, R. and Zuberi, R. (2004) Organochlorine concentrations in various fish from different locations at Karachi coast. Marine Pollution Bulletin, 49, 597-601. doi:10.1016/j.marpolbul.2004.03.019

[42] Saqib, T.A., Naqvi, S.N.H., Siddiqui, P.A. and Azmi, M.A. (2005) Detection of pesticide residues in muscles, liver and fat of 3 species of Labeo found in Kalri and Haleji lakes. Journal of Environmental Biology, 26, 433-438.

[43] Ahad, K., Hayat, Y., Ahmad, I. and Soomro, M.H. (2001) Capillary chromatographic determination of pesticide residues in ground water of Mardan division. Nucleus, $\mathbf{3 8}$, 145-149.

[44] Ahad, K., Mohammad, A., Mehboob, F., Sattar, A. and 
Ahmad, I. (2006) Pesticide residues in Rawal Lake, Islamabad, Pakistan. Bulletin of Environmental Contamination and Toxicology, 76, 463-470. doi:10.1007/s00128-006-0944-8

[45] Tariq, M.I., Afzal, S. and Hussain, I. (2004) Pesticides in shallow groundwater of Bahawalnagar, Muzafargarh, D.G. Khan and Rajan Pur districts of Punjab, Pakistan. Environment International, 30, 471-479. doi:10.1016/i.envint.2003.09.008

[46] Daily Dawn News Paper (2009) February 15, 2009.

[47] Gearhart, J.M., Jepson, G.W., Clewell, H.J., Andersen, M.E. and Conolly R.B. (1994) Physiologically based pharmacokinetic model for the inhibition of acetylcholinesterase by organophosphate esters. Environmental Health Perspectives, 102, 51-60.

[48] Bushnell, P.J., Kelly, K.L. and Ward, T.R. (1994) Repeated inhibition of cholinesterase by chlorpyrifos in rats: Behavioral, neurochemical and pharmacological indices of tolerance. The Journal of Pharmacology and Experimental Therapeutics, 270, 15-25.

[49] Husin, L.S., Uttaman, A., Hisham, H.J., Hssain, I.H. and Jamil, M.R. (1999) The effects of pesticides on the acti- vity of serum cholinesterase and current perception threshold on the paddy farmers in the Muda agricultural development area, MADA, Kedah, Malaysia. The Medical Journal of Malaysia, 54, 320-324.

[50] Ohayo-Mitoko, G.J., Kromhout, H., Simwa, J.M., Boleji, J.S. and Heederik, D. (2000) Self reported symptoms and inhibition of acetyl-cholinesterase activity among Kenyan agricultural workers. Occupational \& Environmental Medicine, 57, 195-200. doi:10.1136/oem.57.3.195

[51] Azmi, M.A., Naqvi, S.N.H., Azmi, M.A. and Aslam, M. (2006) Effects of pesticide residues on health and differrent enzyme kevels in the blood of farm workers from Gadap (rural area) Karachi-Pakistan. Chemosphere, 64, 1739-1744. doi:10.1016/j.chemosphere.2006.01.016

[52] Khalaf-Allah, S.S. (1999) Effects of pesticide water pollution on some hematological, biochemical and immunological parameters in Tilapia nilotica fish. Deutsche Tierärztliche Wochenschrift, 106, 67-71.

[53] El-Saeed, W.Y. and Hassan, M.H. (2000) Chronic Lymphocytic leukemia in Egyptain farm workers exposed to pesticides. East Mediterrian Health Journal, 5, 960-966. 